\title{
STUDY OF PLASMA FIBRINOGEN IN CASES WITH HYPERTRIGLYCERIDEMIA
}

\author{
Rehana Aziz ${ }^{1}$ Mahmudul Haque ${ }^{2}$ Md Sirajul Islam Chowdhury ${ }^{1}$ \\ Sankar Kumar Ghose ${ }^{3}$ M A Taher ${ }^{4}$ Md Tipu Sultan ${ }^{5}$
}

\begin{abstract}
The present study is designed to estimate and observe plasma fibrinogen content in persons with hypertriglyceridaemia. Fifty individuals age ranging from 30-55 years with some definite criteria with a control group were included in this study. A significant difference was observed in this study where the mean serum fibrinogen content in study cases was $245 \mathrm{mg} / \mathrm{dl}$ and that of control was 214.0 $\mathrm{mg} / \mathrm{dl}$. The mean triglyceride in cases was 360.8 $\mathrm{mg} / \mathrm{dl}$ which is significantly higher than that of control $(\mathrm{p}<0.005)$. A strong association between triacylglycerol and fibrinogen was seen in this group.
\end{abstract}

\section{Introduction}

There is a strong association between lipids especially triacylglycerol rich lipoproteins and fibrinogen, Plasminogen Activator inhibitor (PAI-1) and activation of factor VII. In addition, vascular function, especially endothelial cell physiology has been shown to be compromise in the presence of multiple risk factors and to be improved with intensive therapy aimed at reducing risk factors, especially plasma lipoprotein levels ${ }^{1}$. The implications are important for clinical practice. Basic research is providing us with a better understanding of the molecular interactions between lipoproteins and haemostatic factors. Further work in the field of haemostatic factors has been shown that fibrinogen, activated coagulation factor VII, spontaneous platelet aggregation, and elevated levels of PAI-1 are all associated with coronary artery disease ${ }^{2}$.

1. Assistant Professor of Biochemistry, Chittagong Medical College, Chittagong

2. Professor of Biochemistry, Chittagong Medical College Chittagong

3. Lecturer of Biochemistry, Chittagong Medical College, Chittagong

4 Assistant Professor of Physiology, Chittagong Medical College, Chittagong

5. Assistant Professor of Virology, Chittagong Medical College, Chittagong

Correspondence : Dr Rehana Aziz
The characterization of lipoprotein (a) has been suggested a role for decreased fibrinolysis by apolipoproteins (a) and accelerated atherosclerosis ${ }^{3}$. Hypertriglyceridaemia is one of the commonest lipoprotein abnormalities found in general population and patients after myocardial infarction ${ }^{4}$ and some studies have suggested that plasma triacylglycerol is an independent risk factor for ischemic heart disease (IHD) .

\section{Materials and methods}

A cross sectional comparative study. Plasma fibrinogen and serum triglycerides of 50 men (due to non availability of female) age ranging from 30 55 years with known history of hypertriglyceridaemia but no history of smoking, alcohol consumption and diabetes were estimated and compared with the results of the normotriglyceridaemic individuals.

Tables

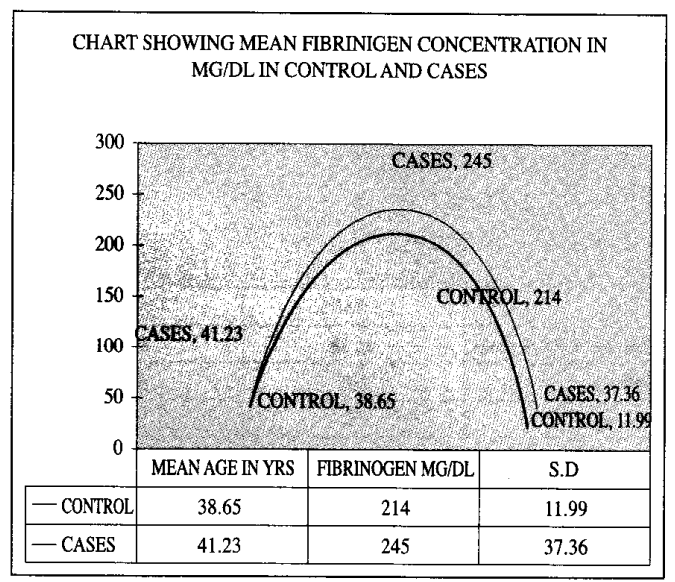

The mean fibrinogen in $\mathrm{mg} / \mathrm{dl}$ in cases was significantly higher than that of control. $(\mathrm{p}<0.05)$

\section{Discussion}

In this study the mean serum fibrinogen content in cases $245 \mathrm{mg} / \mathrm{dl}$ and that of control was $214.0 \mathrm{mg} / \mathrm{dl}$. The statistical difference by unpaired't' test the ' $p$ ' is $<0.05$.The triglyceride mean in cases was 360.8 $\mathrm{mg} / \mathrm{dl}$ which is significantly higher than that of control $(\mathrm{p}<0.005)$. A drift is seen in such observation 


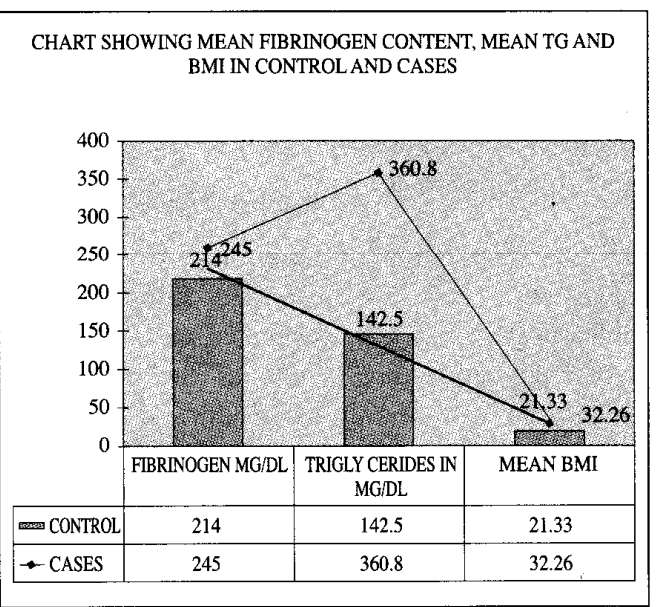

Mean Serum triglycerides in cases was significantly higher than that of control. $(\mathrm{p}<0.005)$.

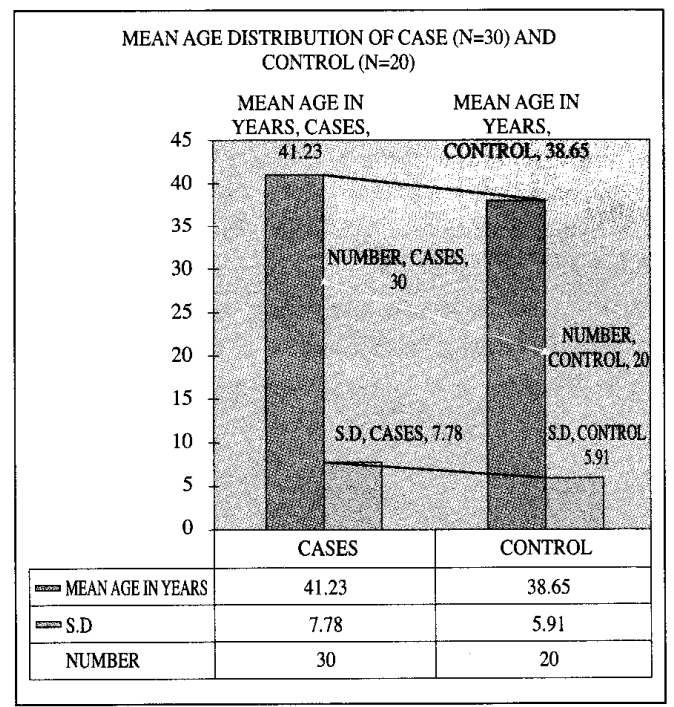

where the inference is that the more the triglycerides, more is the fibrinogen content of plasma of the study population.

Fibrinogen has been identified as an independent risk factor for cardiovascular disease and associated with traditional cardiovascular risk factors. Also, the role of elevated fibrinogen in thrombosis suggests that it may be on the causal pathway for certain risk factors to exert their effect.

Hypertriglyceridaemia is one of the commonest lipoprotein abnormalities found in general population and patients after myocardial infarction ${ }^{6}$.
Some studies have suggested that plasma triacylglycerol is an independent risk factor for ischaemic heart disease (IHD) but this has not been a consistent finding 5 .

Hypertriglyceridaemia may be designated when there is persistent rise of fasting triacylglycerol above normal level. Desired level of fasting triacylglycerol is below $200 \mathrm{mg} / \mathrm{dl}^{7}$. As a working role the desired level of serum triacylglycerol concentration is $<2.2 \mathrm{mmol} / \mathrm{L}$ or $200 \mathrm{mg} / \mathrm{dl}^{8}$.

It is well recognized that atherogenesis, the result of the interaction of certain lipoproteins with cells of vessel wall, is of major importance in the pathogenesis of coronary artery disease ${ }^{10}$. Recently it has been increasingly recognized that thrombogenesis contributes to nearly all deaths due to coronary artery disease ${ }^{10}$. The concepts of "increased thrombotic tendency" and of "hypercoagulability", defined as an increased rate of in vivo thrombin generation, are therefore relevant to the pathogenesis of Coronary Artery Disease $(\mathrm{CAD})^{9}$.

An equally significant influence has been demonstrated for plasma TG level that has an apparent procoagulant activity. Factor VII coagulant activity and plasma fibrinogen concentrations were significant predictors of IHD and were associated with increased TG levels ${ }^{11}$.

\section{Conclusion}

Increased level of fibrinogen in plasma in this study subjects with hypertriglyceridemia as observed may be included as a possibility of coronary thrombosis. The acceptability and validity of this study need recommendations for further extension of such with population at large precise inclusion and exclusion criteria along with socioeconomic and demographic profile.

\section{References}

1. Fuster V, Badimon L, Badimon JJ and Chesbro $\mathrm{JH}$. The pathogenesis of coronary artery disease and the acute coronary syndrome. $\mathrm{N}$ Eng $\mathrm{J}$ Med 1992; 326: 342-350

2. Hamsten A, Wiman B, Faire DU, Blomback M. Increased plasma levels of a rapid inhibitor of $t-$ PA in young survivors of MI. N Eng J Med $1985 ; 313: 1557-1563$

3. Jacques G Jr and Jeffrey SC. Clustering of cardiovascular risk factors: Targeting High-risk individuals. Am J Cardiol 1991; 76: 8A-20A 
4. Gustafson A, Elmfeldt D, Wilhelmsen I, Tibblin G. Serum lipids and lipoproteins in men after myocardial infarction compared with representative population sample. Circulation 1972; 46: 709-716

5. Hulley SB, Rosenman RH, Bawol RD, and Brand RJ. Epidemiology a guide to clinical decisions : The association between triglycerides and coronary heart disease. N Eng J Med 1973; 48: 243-256

6. Gustafson A, Elmfeldt D, Wilhelmsen I, Tibblin G. Serum lipids and lipoproteins in men after myocardial infarction compared with representative population sample. Circulation 1972; 46: 709-716

7. Stein EA, Myers GL. Lipids, Lipoproteins, and Apo-lipoproteins. Teitz Text Book of Clinical Chemistry. W.B. Saunders Company, Philadelphia. $2^{\text {nd }}$ edn. 1994; Pp 1002-1081

8. Isselbacher $\mathrm{KJ}$, Braunwald $\mathrm{E}$, Wilson JD, Martin JB, Fauci AS, Kasper DL. Harrison's Principle of Internal Medicine. $14^{\text {th }}$ edn.1998; 2: 2059-2069

9. Mitropoulos K A. Hypercoagulability and factor VII in hypertriglyceridemia. Seminars in thrombosis and haemostasis 1988; 14 (3): 246-252

10. Meade TW, Chakrabarti R, Haines AP, North WRS, Stirling Y. Haemostatic , Lipid and blood pressure profiles of women on oral contraceptives containing $50 \mu \mathrm{g}$ or $30 \mu \mathrm{g}$ oestrogen. Lancet. 1977; 11: 948-951

11. Meade T W, Mellows S, Brozovic M, Millar G J, North W R S, Stirling Y, Chakrabarti R, Thompson S G, Haines A P, Imeson $J$ D. Haemostatic function and ischaemic heart disease; Principal results of the Northwick Park Heart study. Lancet 1986; September 6: 533-537 